was smaller in size. They were polished with great care, and in shape resembled certain Scandinavian stone axes. From inquiries which he made, he came to the conclusion that in recent times there existed in the centre of the Malay peninsula a people wholly ignorant of metals, and he asks whether these "fire apes" are a remnant of the aborigines, who were overwhelmed by a Negrito invasion, or whether they are merely Sakayes who fled before the Malays. The Sakayes, it should be noted, preserve a tradition of the use of stone implements, and it is probable that before the Malay invasi on they knew nothing of metals. It is curious to notice that the Malays, who frequently find stone axes in the soil, called them "thunderstones," believing that they proceed from a thunderbolt, thus reproducing an old Breton notion in the centre of the Malay peninsula.

IVE have more than once referred to the extraordinary diver sity and confusion of the names of States and towns in the eastern half of the Indo-Chinese peninsula. The Marquis d'Hervey de Saint-Denys, well-known for his Chinese researches, has recently read a paper on this subject before the Paris Academy of Inscriptions, which throws much light on the history of this nomenclature. In the sixth century of our tra the Chinese, regarding the populations of the present Kuantung, Kwangsi, and Tunquin as barbarians, called them Yuen. When the present Tonquin was conquered and reduced to a Chinese province, they called it Kiao-chi or Kia chow, from the name of the capital, the Hanoi of our days. In 756 they established in Tonquin a great district, which they styled the Annam, or "pacificator of the south." 'This is the origin of the present designation. In the fifteesth century Annam, then become a feudatory kingdo $"$, was divided into two principalities : the Wesiern Court, Si-tong, and the Eastern Court, Tonquin hence the latter name. In 1775 the kingdoms of Annam and Cochin China were destroyed by a rebellion, and the last king of the former died at Pekin, whither he had fled. The King of Cochin China, however, succeeded in recovering his throne, and in adding, with the consent of the Chinese, Annam to his dominions. But, in ratifying this union, the Emperor of China bestowed a new name on the whole, Yue-nan. The writer concludes that the country called Annam by the Chinese never went beyond the seventeenth parallel of latitude, and that in every document in which the title occurs the present Tonquin is really meant. It would thus appear that there are, historically, only two countries on the east coast of the peninsula, viz. Annam (which is 'Tonquin, and nothing more) and Cochin China. But this leaves the present Annam to be accounted for. Possibly nothing short of an International Geographical Congress will succeed in producing a simple uniform nomenclature for this regiun.

The Rerue Scientifique bases the following conclusions on the climate of Tonquin on the evidence given by medical and sanitary experts before the recent Commission of the French Chamber on the subject. Compared with Cochin China, Tonquin is not unhealthy; from September to April there is regular spring, and it is from May to October that the heat is almost insupportable. Except in the mountains, which are dreaded by the natives, and in the forests in the neighbourhood of Hung-hoa, there are no deadly fevers as in Cochin China; especially are there no serious diarrhœas as in the latter. In the delta of the Red River, cultivation and vegetation render it healthy. It is doubtful whether cholera is endemic in Tonquin; the last epidemic appears to have been imported from the Pescadores, and it attacked natives rather than Europeans. But sunstroke is rather prevalent. 'Two years is the limit assigned for the residence of troops having to undergo great latigue, with an insufficient quantity of good food; but on occasion this stay may be prolonged without harm to three or four years. Merchants and officials may safely spend fifteen to twenty years in the country.

A T the meeting of the Geographical Society of Paris on January 8, M. Duveyrier described some observations made at 'Tuggurt in 1860, from which he calculated the latitude at $33^{\circ} 7^{\prime} \mathrm{o}^{\prime \prime}$ and the longitude at $3^{\circ} 36^{\prime} 24^{\prime \prime}$ east of Paris. M. Le Chatelier sent several notes relating to the southern part of Algeria.

THE Compte rendu, No. I, I886, of the Paris Geographical Society, contains a suggestion from M. Alphonse de Candolle referring to the want in geographical books and works of travel of an analytical inclex. These works, he says, contain information on natural history, agriculture, mines, ethnography, lan- guage, arts, religion, \&c., which interest all classes of students, but it is scattered throughout the various works, and few have the patience or the time to get at them by an attentive perusal of the whole. He has often experienced this want himself in preparing his botanical geography, and more recently the work on the origin of cultivated plants. As models of indices he points to Darwin's works, and adds that the more detailed the index is the better. He therefore invites the Society to encourage the addition of indices to geographical works.

THE last Bulletin (No. 4, 1885) of the same Society contains the full text of M. Velain's geographical and ethnographical sketch of French Guiana, and the basins of the Yari and Paru, affluents of the Amazon, based on Dr. Crevaux's exploration; of M. de Saint-Pol Lias's account of his journeys in Sumatra and Malacca ("Atché and Péralk"); and of the journeys of M.M. Senèze and Noetzli in Ecuador and Peru in $1876-77$.

Globus (No. 5, 1886) contains an article by Prof. Blumentritt on the tribe of Guinaus of Abra, in Luzon, based on a communication by Lieut. 'Trullens, of the Spanish Army, to the Boletin of the Philippine Society of the Amigos del Pais. The article describes the houses, mode of life, manners and customs of the tribe. They are confirmed head-hunters, notwithstanding the presence of Spanish troops and police in their territory. Their superstitions, Prof. Blumentritt says, go to strengthen the theory that the religious notions of the Malays all over the Archipelago are broadly the same. It is noteworthy that he laments the general ignorance of ethnology displayed by most Spanish writers on the Philippine races.

\section{THE LUMBAR CURVE IN MAN AND APES ${ }^{1}$}

I $\mathrm{N}$ this investigation the fresh spines of twelve Europeans, of four anthropoids, of fifteen different species of the lower apes, and several quadrupeds were examined. In each case the body was frozen, and then divided by a saw in the mesial plane. When still in the frozen condition a tracing was taken of the outline of the body, and of the centra of the vertebræ. The results obtained all tend to minimize the importance of the lumbar curve as a distinctive character of any special group. It is present in a well-marked form not only in the chimpanzee, but also in most. of the lower apes, and even, under certain condition;, in some quadrupeds (i.e. bear). In the chimfanzee the quality of the curve is identical with that of man : it only differs in degree. The latter point could not be absolutely determined, as the four anthropoids examined were little over four years old, and yet the degree of curve was much greater than that of a child of six-indeed it was comparable with that of a child of thirteen.

The second part of the memoir dealt with the adaptation in form of the vertebral bodies to the lumbar curve. By measurements it can be established that in the low races the lumbar curve is not stamped upon the spine so firmly as in the case of the Europeans. In other words, the European lumbar vertebræ are moulded in accordance with the curve, whilst the corresponding vertebre of the low races are not.

Taking the anterior vertical depth of each vertebral body as roo, the following indices were obtained:-

MAN

\begin{tabular}{|c|c|c|c|c|c|c|c|}
\hline & & $\begin{array}{l}7^{76} \\
\text { Eurc- } \\
\text { peans }\end{array}$ & $\begin{array}{c}17 \\
\text { Aus- } \\
\text { tralians }\end{array}$ & $\begin{array}{c}3 \\
\text { Tas- } \\
\text { manians }\end{array}$ & $\begin{array}{l}\text { Bush- } \\
\text { men }\end{array}$ & $\begin{array}{l}23 \\
\text { Anda- } \\
\text { maris }\end{array}$ & $\begin{array}{c}\text { ro } \\
\text { Negroes }\end{array}$ \\
\hline $\begin{array}{l}\text { Five lower } \\
\text { true } \\
\text { wertebre }\end{array}$ & $\mid \begin{array}{l}a \\
b \\
c \\
d \\
e\end{array}$ & $\begin{array}{r}\text { IO6.1 } \\
\text { IOI.4 } \\
97 \cdot 2 \\
93 \cdot 5 \\
81.6\end{array}$ & $\begin{array}{r}119^{\circ} 8 \\
1130^{\circ} \\
113.6 \\
103.9 \\
90.4\end{array}$ & $\begin{array}{r}\text { I I 5. I } \\
\text { I09.9 } \\
\text { X10.1 } \\
\text { IO9.5 } \\
92^{\circ} 4\end{array}$ & $\begin{array}{r}\text { I I5.9 } \\
\text { I I3.4 } \\
\text { I09.9 } \\
\text { I00.8 } \\
95^{\circ} 3\end{array}$ & $\begin{array}{r}\text { II } 2.6 \\
\text { II } 6.2 \\
\text { I08. } \\
\text { 102.6 } \\
9 I^{2} \cdot 4\end{array}$ & $\begin{array}{l}\text { I I } 3.5 \\
\text { II I. } \\
\text { IO5.9 } \\
\text { IO } 5^{\circ} \text { I } \\
92\end{array}$ \\
\hline Average ind & & $95 \cdot 8$ & $107 \cdot 8$ & $107 \cdot 2$ & $106 \cdot 6$ & $104 \cdot 8$ & 1054 \\
\hline
\end{tabular}

I Abstract of a Paper on "The Lumbar Curve in Man and the Apes, with an Account of the Topographical Anatomy of the Chimpanzee." By D. J. Cunningham, M.D. (Univ. Dub. Professor of Anatomy in Trinity
College, Dublin. Read before the Royal Irish Academy, January 26, r886. 


\begin{tabular}{|c|c|c|c|c|c|c|c|}
\hline \multicolumn{8}{|c|}{$\mathrm{APE}$} \\
\hline & $\begin{array}{c}\text { Goril- } \\
\text { las }\end{array}$ & $\begin{array}{c}\text { Chim- } \\
\text { panzees }\end{array}$ & Orangs & $\begin{array}{c}6 \\
\text { Gib- } \\
\text { bons }\end{array}$ & $\begin{array}{c}2 \\
\text { Ba. } \\
\text { bo ons }\end{array}$ & $\begin{array}{c}3 \\
\text { Ma- } \\
\text { caques }\end{array}$ & $\begin{array}{l}\mathrm{x} \\
\text { Colo- } \\
\text { bus }\end{array}$ \\
\hline $\begin{array}{c}\text { Five lower } \\
\text { true } \\
\text { vertebræ }\end{array}$ & $\begin{array}{l}115.3 \\
\text { III } 17 \\
\text { III } 3 \\
\text { IO5.3 } \\
\text { IOI } 9\end{array}$ & $\begin{array}{l}125.3 \\
1117.1 \\
116.4 \\
\text { II } 6.1 \\
115.8\end{array}$ & 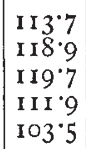 & $\begin{array}{l}\text { I I 2.8 } \\
\text { I08.8 } \\
\text { IO7.5 } \\
\text { I06. } \\
\text { I04. } 1\end{array}$ & $\begin{array}{r}117.7 \\
\text { I } 20.6 \\
\text { IO } 8 \\
\text { IO } 7.3 \\
92.8\end{array}$ & $\begin{array}{l}109^{\circ} 7 \\
\text { I07.8 } \\
103 \\
103.2 \\
96^{\circ} \cdot 2\end{array}$ & $\begin{array}{c}103.8 \\
103.8 \\
103.8 \\
108 \\
90.4\end{array}$ \\
\hline Average inde & $108 \cdot I$ & II 7.5 & I I 2.9 & $107^{\circ} 1$ & $108 \cdot 5$ & $103 \% 7$ & 1024 \\
\hline
\end{tabular}

It can be proved in many ways that the lumbar curve of the spine is more marked in the human female than in the male. The methods adopted for the elucidation of this point were : $(\mathrm{I})$ tracings of mesial sections of the frozen spines of the two sexes (2) Measurements of the anterior and posterior surface of the lumbar region; and (3) measurements of the individual Jumbar vertebræe

The difference between the indices of the vertebræ of the two sexes are not confined to Europeans, but are also observed in four of the five lower races examined, as will be seen from the following table :-

\begin{tabular}{|c|c|c|c|c|c|c|}
\hline \multirow[b]{3}{*}{$\left.\begin{array}{l}\text { Average index } \\
\text { of the five lum- } \\
\text { bar vertebræ ... }\end{array}\right\}$} & \multicolumn{2}{|c|}{ lrish } & \multicolumn{2}{|c|}{ Andamans } & \multicolumn{2}{|c|}{ Negroes } \\
\hline & $21 \delta$ & $23 \%$ & 145 & $9 ?$ & $7 \delta$ & $3 ?$ \\
\hline & $96 \cdot 2$ & 93.5 & $106 \cdot 3$ & 1024 & 106 & 103.4 \\
\hline & \multicolumn{3}{|c|}{ Australians } & \multicolumn{3}{|c|}{ Tasmanians } \\
\hline & \multicolumn{2}{|c|}{ Iot } & 49 & $2 t$ & \multicolumn{2}{|c|}{19} \\
\hline $\begin{array}{l}\text { Average index } \\
\text { of the five lum. } \\
\text { bar vertebræ.... }\end{array}$ & \multicolumn{2}{|c|}{110.1} & $103^{\prime} I$ & $108 \cdot 5$ & \multicolumn{2}{|c|}{1047} \\
\hline
\end{tabular}

It can be shown that the indices of the lumbar vertebræ of a given European spine are in strict accordance with the degree of lumbar curve. But, whilst this is the case, the difference between the anterior and posterior vertical diameters of the vertebral bodies is so slight (as Weber has observed) that it can have little effect in producing the lumbar curve. The formadaptation of the vertebral bodies must, therefore, he regarded as the consequence, and not as a cause, of the curve: at the same time it cannot be due to an immediate and mechanical influence operating upon the vertebral bodies during the life of the individual. If it were so, the same characters would be present in the lumbar vertebræ of the low races, and even of the anthropoid. It is an hereditary condition.

The European, who leads a life which rarely necessitates his forsaking the erect attitude excent as an intermittent occurrence, and then for short periods, has sacrificed in the lumbar part of the vertebral column flexilility for stability. It is evident that the deeper the bodies of the vertebræ grow in front, the more permanent, stable, and fixed the lumbar curve will become, and the more restricted will be the power of forward-bending in this region of the spine. The savage, in whose life agility and suppleness of body are of so great an account, who pursues game in a prone position, and climbs trees for fruit, \&c., preserves the anthropoid condition of vertebræ, and in consequence possesses a superior flexibility of the lumbar part of the spine.

\section{SNOW-COVERING AND THE WEATHER}

$D^{\mathrm{R}}$. WOEIKOF, who is one of the meteorologists of the modern school, has long entertained a deep conviction that meteorology ought not to limit itself to a mere observation of those few instruments which for nearly fifty years have constituted the plant of meteorological Observatories. In the development of its general laws and the application of them to forecasts of weather, it must widen the circle of its observations, and take into account those factors upon which weather and climate depend in each given locality. For the past fifteen years he has devoted his time to the study of local climates and their dependence upon local causes, such as the local deflections of the paths of cyclones and anticyclones; the proximity of seas, steppes, marshes, and forests, and the local heating and cooling of the ground. His chief work, published in Russian, entitled "The Climates of the Globe," is most valuable, on account of the wide linowledge it evinces of the various circumstances on which climate depends, especially with regard to the immense plains of Russia.

The influence of the snow on climate, of its depth and consistency, the time of its first appearance and disappearance, the evaporation from its surface, the purification of air when it has fallen, and a variety of minor circumstances, the importance of which has been insisted on by Dr. Woeik of since 1872 , are all referred to. Unhappily, observations on snow are very few and imperfect, and in a paper recently read before the Russian Geographical Society, and now printed in its Memoirs (xv, 2), he returns to the subject, illustrating the importance of such observations by a few well-chosen examples.

The year 1877 was a striking instance of how the absence of snow was accompanied by a far less notable lowering of temperature during the prevalence of anticyclones than would have been the case had the soil been covered with snow. In 1877 there was no snow in Eastern Russia until Christmas, and in November and December the anticyclones occurred, accom. panied by no wind, or only by feeble breezes. Quite bright weather lasted in December for more than ten days; and still in the region which remained uncovered with snow no great cold was experienced as usually happens in such circumstances : the minima were $8^{\circ}$ to $9^{\circ}$ above their average values. The same conditions were noticed during the winters of 1879.80 and $\mathbf{1 8 8 1}$ 82, in West Europe, as shown by Dr. Billwiller in the Zeitschrift fiir Meteorologie for 1882.

In Dr. Woeikof's opinion the relatively high mean temperature of November, as compared with March, in South-East Russia and the Kirghiz Steppe may be explained by the circumstance that in these localities the soil usually is not covered with snow in November; and thus, not being separated from the air by the snow, which is a bad conductor of heat, it rather contributes to maintain a higher temperature in the air resting on it. On the other hand, towards the end of winter the surface is much cooled and exercises a refrigerating influence on the air. Examples from the United States adduced by M. Woeikof seem also to confirm this view.

The refrigerating influence of a thick covering of snow in the spring and the influence it exercises in retarding the arrival of warm weather is so obvious that it need not be insisted on. A paper was written by M. Woeikof, in 1872 , on this sub. ject; and the very interesting illustrations he has adduced to show the refrigerating influence of a snow-covering during years when snow was abundant, are very striling. He has since returned to this subject in his "Climates of the Globe," and in the paper we mention; and we may consider it quite established that it is precisely to this agency that the relative coolness of the spring months in Russia and Siberia is due. Moreover, it may be considered as certain that when the snow-covering has been thick, and especially when the snow has a harder consistency, the arrival of warm weather will come on late in the spring.

Another result which Dr. Woeik of has established relates to the commencement of first durable frosts. As long as there is no snow, or little, he argues that frosts may begin, but they will not be durable, and the temperature may rise above the freezing-point; but it is the snow-covering, although not very thick, which gives durability to cold weather. It is easy to foresee how important it becomes, in forecasting the weather, to know, both in spring and autumn, if there are, to the north and east of any region, broad spaces covered with snow.

It is useless to insist upon the importance of an exact knowledge of the depth and consistency of the snow for forecasts in. the interests of navigation, especially in countries like Russia, where navigation on so many rivers is carried on only at high water. Several interesting illustrations of this influence are given by the author. In view of these important results, it is 